\title{
Interdisciplinarity and the study of Early Modern sermons
}

\author{
Article \\ Published Version
}

Morrissey, M. (1999) Interdisciplinarity and the study of Early Modern sermons. The Historical Journal, 42 (4). pp. 11111123. ISSN 1469-5103 Available at https://centaur.reading.ac.uk/25325/

It is advisable to refer to the publisher's version if you intend to cite from the work. See Guidance on citing.

Published version at: http://www.esaim-cocv.org/action/displayAbstract?

fromPage $=$ online \& aid $=5595 \&$ fulltextType $=$ RV\&fileld $=$ S0018246 X99008833

Publisher: Cambridge University Press

All outputs in CentAUR are protected by Intellectual Property Rights law, including copyright law. Copyright and IPR is retained by the creators or other copyright holders. Terms and conditions for use of this material are defined in the End User Agreement.

www.reading.ac.uk/centaur

\section{CentAUR}

Central Archive at the University of Reading

Reading's research outputs online 
The Historical fournal, 42, 4 ( I999), pp. I I I I-I I 23 Printed in the United Kingdom

(C) I 999 Cambridge University Press

\title{
HISTORIOGRAPHICAL REVIEWS
}

\section{INTERDISGIPLINARITY AND THE STUDY OF EARLY MODERN SERMONS}

\author{
MARY MORRISSEY \\ University of Aberdeen
}

\begin{abstract}
A B S T R A C T. This review surveys the study of early modern sermons by historians and literary critics in recent years. It argues that sermons are becoming more important to research in the period, particularly given the revisionist historians' emphasis on religious politics and the shift to historicism in literary studies. None the less, sermons are rarely scrutinized by either group of scholars in a way that utilizes both their rhetorical artfulness and their political engagement: they are not studied as both texts and events. This is partly a result of the different perspectives from which they have been examined by previous generations of scholars. Although two recent monographs, Peter McCullough's Sermons at court and Lori Anne Ferrell's Government by polemic, demonstrate ways in which this might be corrected, it must still be acknowledged that much work remains to be done.
\end{abstract}

In two monographs on early modern preaching published recently, the writers insist on the importance of preaching to the study of early modern politics and lament the neglect of the subject by historians and literary scholars. In his Sermons at court, Peter McCullough states that sermons were the most 'visible, frequent, and carefully noted literary genre at court'. In order to adjust the 'historical scholarly obsession with the royal patronage of public players', McCullough insists that 'the sermon - not the Shakespearean drama, and not even the Jonsonian masque - was the pre-eminent literary genre at the Jacobean court'. Likewise, in Government by polemic, Lori Anne Ferrell writes that 'sermons, not masques, were the major organs of political selfexpression at the Jacobean court. Their audience extended well beyond Whitehall.' And yet both writers contrast this influence with the neglect of the subject by modern scholars. McCullough is right to say that the court pulpit, "the pulpit at the very heart of political power', has been 'virtually ignored'. Ferrell attributes the fact that 'sermons are almost completely ignored in the studies of political language that abound for this period' to the 'methodological slipperiness' in which their study is caught. ${ }^{2}$ Actually, this complaint about the neglect of sermons is old: it was made in 1932, when Fraser

1 Peter McCullough, Sermons at court: politics and religion in Elizabethan and Jacobean preaching (Cambridge, I998), p. 3; Lori Anne Ferrell, Government by polemic: James I, the king's preachers and the rhetorics of conformity, I603-I625 (Stanford, I998), р. г о.

2 McCullough, Sermons at court, p. I ; Ferrell, Government by polemic, pp. I I-I 2. The 'methodological slipperiness' remarked on by Ferrell refers to a comment by Jeanne Shami that sermons have 'tended to fall between the disciplines' in seventeenth-century studies, with which I am in complete agreement: Shami, 'Introduction: reading Donne's sermons', fohn Donne Fournal, I I (I992), p. 2. 
Mitchell published his influential English pulpit oratory from Andrewes to Tillotson. 'For one person who witnessed a play or ten who happened to read it', he claimed, 'thousands may, without exaggeration, be said to have attended sermons, or afterwards studied them from shorthand notes or in printed copies. ${ }^{3}$ We might suspect, therefore, that sermons are one of those deservedly neglected areas of historical investigation whose devotees might well be accused of special pleading. But the claims made by McCullough and Ferrell carry considerable weight: in particular, revisionist attempts to demonstrate the importance of religion and religious culture to the study of early modern England would seem to necessitate a thorough investigation of the era's most characteristic religious genre. Neither are McCullough's and Ferrell's claims exaggerations: in ballpark figures, I would estimate that sermons make up about i 5 per cent of the entries in Pollard and Redgrave's Short title catalogue of English books, I 475-I64o. Those entries range in size from single sermons to collections of anything from two to ninety-six or more. (I have made no attempt to estimate the percentage for the Wing or eighteenth-century catalogues.) Paul Seaver, who has traced the history of the Elizabethan 'lectureships', estimated that about one hundred sermons were preached in London every week, a figure that makes an interesting comparison with the thirteen theatres recorded for the period (not all of which were operating at the same time, of course). As politically and socially engaged writing, sermons are also one of the most important sources we have for the study of early modern ideology, not least because of the esteem in which contemporaries held them as rhetorical compositions. Whereas John Donne was content to leave his poetry to the vagaries of manuscript transmission, he devoted a great deal of time in his final years to preparing his sermons for publication. ${ }^{4}$

The reasons for the neglect of sermons in early modern studies are not hard to find: neither the phenomena of preaching nor the conventions of early modern sermon composition are as familiar to us as they need to be in order to generate the scholarly interest and attention that the subject merits. Early modernists are not accustomed to studying sermons both as events and texts. This failure is partly because of the volume of material to be studied, partly a product of the changing emphasis in historical studies and partly a result of the changing emphasis in Renaissance literary studies. There is a vast quantity of sermon texts from the early modern period that need to be explored. Historians have not, until recently, thought it necessary to 'read rhetorically', to treat texts as anything other than brute 'primary sources'. Literary critics have studied sermons from a perspective that did not, until recently, seem to relate to the preoccupations of their colleagues in history. In this review, I will examine the use of sermons by historians and literary critics and argue that sermons can only be studied accurately and fruitfully when they are studied across these two disciplines. Movements in this direction are beginning to be made, a trend evident from these two latest monographs on Jacobean court preaching.

First, the study of early modern preaching proves a daunting task to anyone in the initial stages of their research. The volume of primary material is formidable and the secondary works that might guide one through this forest of print are still few and far between. Indeed, much of the work done in the last twenty or thirty years has still found

${ }^{3}$ W. Fraser Mitchell, English pulpit oratory from Andrewes to Tillotson: a study of its literary aspects (London, I932), pp. 3-4.

${ }^{4}$ P. S. Seaver, The puritan lectureships (Stanford, I978), p. I25; R. C. Bald, Fohn Donne, a life (Oxford, I970), pp. 479-80, 522-3, $53^{2}$.

\section{CAMBridge JDURNALS}


it necessary (at least partly) to set the foundations for the proper investigation of this subject. We possess no bibliography of sermons for the early modern period. Alan Fager Herr's bibliography of Elizabethan sermons has not been updated and we do not even have such a bibliography for the early or later Stuart or early Georgian periods. ${ }^{5}$ Although Millar MacLure's Register for Paul's Cross has recently been updated and a calendar of Fast sermons is included in John F. Wilson's monograph Pulpit in parliament, there are still very many pulpits for which we cannot even quantify the amount of source material available. ${ }^{6}$ Astonishingly, given their importance to the subject of religious politics, the sermons delivered in the chapel royal for the Elizabethan and Jacobean periods have only now been calendared in McCullough's new monograph. A real innovation here is the publication of this calendar in electronic form on a floppy disk. This makes searching the database much simpler and diminishes the need for extensive indices. Two as yet unpublished studies of preaching rhetoric have supplied us with bibliographical information on sermons in a more traditional format: Barbara White's 'Assize sermons' and James Caudle's 'Measure of allegiance' provide exhaustive information on the extant sermons preached at (respectively) assizes I660-I 720 and on Georgian politics (the accessions of George I, II, and III and the Jacobite rebellions of I 7 I 5 and I 745/6). ${ }^{7}$ New electronic and internet search engines will remedy this problem to some extent, making the identification of material easier. None the less, the tedium of sorting through the hundreds of entries for the keyword 'sermon' when trying to identify material on a particular topic, date, or pulpit already make this a timeconsuming and dispiriting task. A more thorough and useful database, searchable by scriptural text and pulpit rather than merely author or date, would be an invaluable aid to the study of early modern religion generally. At the level of prescriptive theory, there is a similar lack of basic research. As yet, we lack a history of English Reformed preached theory. We do not yet know the genealogy of the 'doctrines and uses' system so universally employed by preachers, or a full account of the reaction against 'learned preaching' during the Civil War, or a thorough, historical investigation of the abrupt change in sermon styles in the r67os.

Secondly, the study of sermons has been rather disconnected: those historians who have used sermons have treated them either as sources or subjects, not as rhetorical texts. Sermons have served as vital sources both for the history of the Reformation and Protestantism's integration in English political and cultural life. In the first of these fields, we could number a very large group of historians whose focus has been the English Reformation church and who have relied heavily on material from sermons to substantiate their theses on the confessionalization of Tudor England. Patrick Collinson, John Sears McGee, John Morgan, and Paul Seaver have drawn on a huge variety of printed sermons and supporting documents to show the importance of preaching in strengthening the Reformation in England and the culture that grew up

${ }^{5}$ Alan Fager Herr, The Elizabethan sermon: a survey and a bibliography (Philadelphia, I940).

${ }^{6}$ Millar MacLure, The Paul's Cross sermons, I534-1642 (Toronto, I958); Register of sermons preached at St. Paul's Cross, ${ }^{5} 534^{-1642}$, revised and expanded by Peter Pauls and Jackson Campbell Boswell (Ottawa, I989); John F. Wilson, Pulpit in parliament: puritanism during the English Civil Wars, $1640-1648$ (Princeton, I969).

7 Barbara White, 'Assize sermons I640-1720' (doctoral thesis, Newcastle-upon-Tyne, I980); James Joseph Caudle, 'Measures of allegiance: sermon culture and the creation of a public discourse of obedience and resistance in Georgian Britain, I 7 I $^{-1} 7_{60}$ ' (doctoral thesis, Yale, I995).

\section{CAMBRIDGE JDUNALS}


around godly preaching. ${ }^{8}$ Although a glance at the bibliographies of many of these monographs demonstrates their reliance on printed and manuscript sermons as sources, in many the methodology by which that material is investigated is a very crude sort of 'source-mining'. For example, in the days before revisionism became orthodoxy, Richard Greaves, in Society and religion in Elizabethan England, made extensive use of sermons to catalogue the differences between 'puritan' and 'Anglican' ideologies, by a method that appears little more than the compilation of statements on various topics and the grouping of them in opposite columns. So, although both 'Anglicans' and 'puritans' were in broad agreement on the source and proper uses of wealth, 'puritans' were more 'receptive' to 'associating prosperity with godliness' and so gave 'decreased attention' to the dangers of wealth. ${ }^{9}$ The problems with such a 'broad brush' approach are obvious: what use is this distinction if William Whately, the puritan 'roaring boy of Banbury', was happy to pronounce the following from Paul's Cross?

So then, if any man doe find himselfe to stand so disposed in minde, that having enough for the present time, yet he doeth eate up his heart, break his sleepe, disquiet himselfe, \& turne into gaule, that comfort which hee might have in his life, by this unprofitable and overreaching thoughtfulnes: $\mathrm{Ah}$, how shall I doe, if a deare yeare come? howe, if I have so manie children? how if I live till I be so old, or till I be lame or blinde? sure I shall spend all, I shall consume all, I shalbe undone, I shall die a beggar, \& come to gret want \& extremitie, and such like terrible dreams: if any man I say stand thus affected, these things doe most rankly savour of covetousness. ${ }^{10}$

Sermons have also been 'source mined' by political historians. As both Thomas Hobbes and the earl of Clarendon numbered the seditious sermons of puritans among the causes of the English Civil War, it is no surprise that the political impact of preaching has been the subject of historical inquiry for William Haller, Christopher Hill, M. M. Knappen, Hugh Trevor-Roper, and John F. Wilson. ${ }^{11}$ The House of Commons has been shown to have received orations by preachers only too happy to encourage the 'sedition' and 'rebellion' lamented of by Hobbes and Clarendon. ${ }^{12}$ QED, it would seem, for the political uses of the early modern pulpit. Yet the debate was far from over with this less-

${ }^{8}$ Patrick Collinson, The Elizabethan puritan movement (London, I967); idem, The religion of Protestants: the church in English society (Oxford, I 982); idem, Godly people: essays on English Protestants and puritanism (London, I983); J. Sears McGee, The godly man in Stuart England: Anglicans, puritans and the two tables, I620-I67o (Yale, I976); John Morgan, Godly learning : puritan attitudes towards reason, learning and education, ${ }_{5} 56-1640$ (Cambridge, I986); Paul S. Seaver, The puritan lectureships: the politics of religious dissent, ${ }_{5} 560-1662$ (Stanford, I970); idem, Wallington's World: a puritan artisan in seventeenth-century London (London, I985).

9 Richard Greaves, Society and religion in Elizabethan England (Minneapolis, I98 I), p. 554.

10 William Wheatlie [Whately], A caveat for the covetous (i6o9), sig. Clr, p. 3 I.

11 Thomas Hobbes, Behemoth (I679), in Works, ed. Sir William Molesworth ([I839-45]; repr., London, I992), vi, pp. I67, I90-7; Edward Hyde, earl of Clarendon, History of the Rebellion, ed. W. D. Macray (6 vols., Oxford, I 888), III, pp. 56, 65; vi, pp. 40-2; William Haller, The rise of puritanism: or the way to the New Jerusalem as set forth in pulpit and press from Thomas Cartwright to Fohn Lilburne and Fohn Milton (Columbia, I938); idem, Liberty and Reformation in the puritan revolution (Columbia, I 955); M. M. Knappen, Puritanism: a chapter in the history of idealism (Chicago, I 939); Christopher Hill, Society and puritanism in pre-revolutionary England (London, I 964; republ., London, I986); The English Bible and the seventeenth-century revolution (London, I994); Wilson, Pulpit in parliament.

12 H. R. Trevor-Roper, Religion, the Reformation and social change, and other essays (London, I 967); Wilson, Pulpit in parliament. Wilson to some extent acknowledges having taken his cue for this study from Trevor-Roper and from Godfrey Davies, 'English political sermons, I603-i 640', Huntington Library Quarterly, I ( I939), pp. I-22.

\section{CAMBridge JDURNALS}


than-earth-shattering discovery. The insistence of the 'revisionist' historians on the centrality of religion to the breakdown of consensus that precipitated the Givil Wars has caused historians to look again at the political impact and the political content of printed sermons from a new perspective. That insistence stems from the more fundamental aim of the revisionists to resist the anachronising teleology that often accompanies 'grand theory' explanations of the past. In the words of John Morrill:

It was an essential part of the revisionist claim for the particularity of past experience, and for the gulf between our mental world and that of the seventeenth century. Thus I was consciously seeking to assimilate the events in seventeenth-century England to a class of events which belong distinctively to the period under study and not to the social and secular divisions alleged to underlie most modern revolutions. ${ }^{13}$

Uncovering the religious divisions that are now taken to be among the "proximate causes' of the breakdown in consensus in 1642 has led historians to delve into the intricacies of the theological debate conducted from press and pulpit, giving renewed impetus to the study of the political and ideological impact of preaching. When Nicholas Tyacke turned the model of Anglican/puritan opposition (with the puritans as innovators) topsy-turvy in his Anti-Calvinists ( 1987 ), ${ }^{14}$ an important proof he used for a 'Calvinist consensus' were statements on the doctrine of predestination delivered from Paul's Cross during that period. He found not a single reference to predestination that was not consistent with a Calvinist soteriology. Tyacke's argument certainly recognizes the important of the site of these pronouncements (the centrality of Paul's Cross to the religious life of London and its 'tuning' by the government meant the statements made there carried considerable weight). However, we might argue that the doctrinal points 'disputed' between Calvinists and Arminians were considered the least important for 'pastoral divinity', being, as the I622 Directions concerning preachers termed them 'fitter for the schools than for simple auditories'. ${ }^{15}$ As preachers at Paul's Cross were supposed to 'apply' divinity to the here and now of their auditors' lives, rather than discuss systematic theology, perhaps the absence of sustained argument over the 'deepe points' of predestination is only to be expected. A keen sense of the importance of the circumstances of individual sermons or pulpits is more apparent in the work of Peter Lake. In Moderate puritans, Lake shows how the disputes in Cambridge in I 595-6 that led to the production of the Lambeth Articles centred on the promulgation or not of Calvinist doctrines from the pulpits in and around the university. What is most interesting in this for our purposes is Lake's treatment of these sermons as influential events. Rather than compile numerous amorphous statements, he gives the reader a sense of the political impact of controversial pronouncements made in the pulpit: he treats sermons as texts and events rather than as mere 'source material'. Likewise, in his excellent article on 'avant-garde conformity' in court preaching, Lake carefully situates the sermons delivered by Andrewes and Buckeridge in their immediate context, so that the political implications of the sermons' themes and styles become apparent. Although all the elements of the Laudian attack on puritanism might be assembled from Andrewes's sermons (his emphasis on the sacraments and prayer, and his insistence on the subordination of preaching to both), Lake insists that Andrewes 'did not assemble

${ }^{13}$ John Morrill, 'Introduction: England's Wars of Religion', in The nature of the English revolution (London, I993), p. 35.

${ }_{14}$ Nicholas Tyacke, Anti-Calvinists: the rise of English Arminianism, I590-I640 (Oxford, I987), appendix I.

${ }_{15}$ Thomas Fuller, The church history of Great Britain, ed. James Nichols (London, i 868), p. 357.

\section{CAMBRIDGE JDURNALS}


them' as the Laudians would. Andrewes's position in a court still committed to religious consensus and a church dominated by doctrinal Calvinism accounts for this failure to make a policy statement. ${ }^{16}$ Without this appreciation of individual sermons as events, these statements could too easily distort the Jacobean Andrewes. Even more impressive is Lake's discussion of the importance of place and circumstance in preaching, in his article with Michael Questier on speeches and sermons made at the gallows of Catholic priests. The 'heightened spiritual significance' of the condemned man's last words made it of enormous ideological significance, 'a fact which both sides tried to exploit to their own polemic advantage', with a result that neither 'the state' nor the 'martyrs' could claim a clear victory for their interpretation of the events. ${ }^{17}$

Other historians have also begun to treat sermons as texts and events with similar care: Glenn Burgess analyses the language of 'divine right' in court sermons, paying particular attention to the notorious sermons on the 'forced loan' by Robert Sibthorpe and Roger Manwaring. ${ }^{18}$ James Caudle and Tony Claydon are two historians of the later Stuart and Georgian period whose work also shows a great awareness of the importance of sermons as texts and events and not merely as a source of non-literary 'statements'. They emphasize the argumentative structure of these texts and the importance of rhetorical commonplaces in those arguments. Claydon's thesis is that William III and his propagandists did not defend the Glorious Revolution on the basis of legal or constitutional arguments: rather, they used the idea of a 'courtly reformation', built on the commonplaces of providentialism, God's care for the English church, and the king's role in its defence from popery. A centrally important source for this argument is the printed sermons, and in particular the sermons of Gilbert Burnet. Two of Claydon's main points are important for sermon studies: the first is that preaching still proved to be a highly efficient tool of state propaganda at this period; and therefore (Claydon's second point) that the secularism of eighteenth-century elite society did not nullify the political usefulness of religious argument. ${ }^{19}$ James Caudle also denies the dominance of a secular ideology in eighteenth-century England and insists that 'without taking sermons into account both as spoken and printed discourse, we effectively ignore one of the chief ways in which the Georgian Establishment's supporters ... attempted to present the various political doctrines of the kingdom to its constituents and subjects'. Caudle describes the ways in which preachers incorporated the language of political resistance into the 'deck of cards' of constitutional ideas from which they drew in their sermons. By arguing that resistance to a tyrannical or Roman Catholic monarch would be justified, Georgian preachers could laud the constitutional probity, and therefore the native English mindset, of their Hanoverian monarchs. ${ }^{20}$ This 'deck of cards' metaphor is, I think, a very useful way of thinking about the process

16 Peter Lake, Moderate puritans and the Elizabethan church (Cambridge, I 982), pp. 20 I-42; idem, 'Lancelot Andrewes, John Buckeridge and avant-garde conformity at the Court of James I', in The mental world of the facobean court (Cambridge, I99I), pp. I I3-33, Linda Levy Peck, ed., p. I3I.

17 Peter Lake and Michael Questier, 'Agency, appropriation and rhetoric under the gallows: puritans, romanists and the state in early modern England', Past and Present, I53 (I996), pp. $64-$ I07, at p. 75 .

18 Glenn Burgess, 'The divine right of kings reconsidered', English Historical Review, I o7 ( I 992), pp. 837-86; idem, The politics of the ancient constitution: an introduction to English political thought, I603-42 (London, I992), pp. 73-7.

19 Tony Claydon, William III and the godly revolution (Cambridge, I 996), pp. 4-6, 28-33, 83-7.

20 Caudle, 'Measures of allegiance', pp. 26-7, 52. The phrase 'deck of cards' is used in the abstract.

\section{CAMBridge JDURNALS}


of composing sermons from political and religious commonplaces. Commonplaces of argument (or topoi) were headings for the types of argument that a speaker could apply to a particular issue. In preaching, they very often took the form of texts from Scripture, and in such cases, these commonplaces were called proof-texts. Such studies of early modern ideology based around the evolution and manipulation of commonplaces will add greatly to our understanding of the mechanisms by which preaching shaped political opinion.

It is clear, then, that historians of England have recognized the importance of preaching in the evolution of a Protestant ideology and as a site of religious conflict in the seventeenth century. However, that recognition has not yet translated itself fully into the efficient and accurate use of this material: sermons are not treated as texts recording and intervening in events. When sermons are used by historians, they are far too often treated as literal statements, as devoid of deliberate composition and rhetorical artistry as exchequer returns. This leads far too often to the use of sermons in crude 'source mining': individual statements on almsgiving, on obedience to the magistrate, or on the perseverance of the saints are taken out of context and treated as bare axioms rather than elements within a highly wrought rhetorical 'set-piece'. Early modern sermons are complex and carefully structured arguments that begin with a text from Scripture and that use this text to create interpretations capable of providing moral and political instruction in the 'here and now' of the sermons' 'application'. They were presented to the hearers for their moral instruction, and sometimes their enjoyment, as well as their immediate information. The revisionists' wish to reclaim the 'particularity of past experience' has not extended to the way in which we read the documents on which our interpretations of the past are based. It is here that the literary scholar should come into her own.

In this respect, Lori Anne Ferrell's new monograph is a step in the right direction. The methodology used by Ferrell is one that assumes the political implications of religious rhetoric and charts the policy changes in James's reign through the language used by the court preachers. James, she contends, governed 'by polemic'; he allowed his preachers to shape the discourse within which Presbyterianism and English puritanism could be analogized and vilified. Ferrell takes a small number of important commonplaces in Jacobean court preaching - the union of Protestants, the king's authority in the church, the king as Constantine, the king as Solomon, the respect due to the king's authority in adiaphora - and showed how each functioned as 'dual-directional polemical engines of the ecclesiastical policy of James', aimed as much towards puritans in England as they were against recusants or Scottish Presbyterians. None the less, it would be easy to overstate James's ability to direct pulpit polemic and Ferrell does point out that this 'solidarity of purpose' between James and his bishops cannot be assumed to have always been by his design. ${ }^{21}$ There are good reasons for this caveat. We know that most preachers did not write their sermons out fully before delivery, and so there was no way of assuring that the preacher would deliver the 'correct' message from the pulpit. ${ }^{22}$

${ }^{21}$ I am reminded strongly of a point Anthony Milton has made in his recent article on censorship - that the jostling of competing groups for control of the press (and, I would say, by analogy the pulpits) determined what became the orthodoxy: Anthony Milton, 'Licensing, censorship, and religious orthodoxy in early Stuart England', Historical Fournal, 4I (1998), pp. 625-5I ; Ferrell, Government by polemic, pp. 82, i i 6.

${ }^{22}$ On the practice of preaching from notes, see John Sparrow, 'John Donne and contemporary preachers: their preparation of sermons for delivery and for publication', Essays and Studies, i 6 (I93 I), pp. I44-78. It may have been an innovation of William Laud's, while he was bishop of

\section{CAMBridge JDURNALS}


There were enough incidents at the court and Paul's Cross to suggest that preachers sometimes, accidentally or not, got the message 'wrong'. ${ }^{23}$ For the purposes of this review, however, what is most instructive about Ferrell's book is its method of analysis. It is striking that Ferrell, who is by training a historian, should insist on the usefulness of proper rhetorical analysis to historians. She writes:

Yet we can never merely identify rhetorical tropes or discursive contexts and hope to make a simple case for their importance. Historians must show the significance of such strategies; they must uncover the origins of politics in rhetoric ... In this study of sermon polemic, then, we must rediscover something James and his preachers knew instinctively: the unique ability of religious language to shape political action. ${ }^{24}$

This statement forcefully conveys both the importance of sermons to the study of early modern history, but equally the importance of a proper use of this material. The acute sensitivity of an early modern auditory, especially a learned one such as the court provided, to the conventions of preaching rhetoric constrained a preacher in ways that we must appreciate before we can understand his pulpit pronouncements.

The importance of printed sermons as sources for social, cultural, and political history is much more firmly embedded (for obvious reasons) in the historiography of New England, and consequently the scholars in this field have been much quicker to develop interesting methods of analysis that 'place' the individual sermons firmly in their context, so that their social and political impact can be assessed, but which recognize the 'literariness' of these texts. The trail-blazing studies of Perry Miller on the New England Jeremiad set the pace for the investigation of New England ideology through the critical analysis of her most important and characteristic literary form: the sermon. His lead had been followed by scholars of the Jeremiad in particular and the 'New England mind': Sacvan Bercovitch and David Minter have explored the Jeremiad further, both as a literary form and the expressions of a particularly New English Weltanschauung. ${ }^{25}$ Harry Stout and Teresa Toulouse have explored New England

London, to insist that those he appointed to preach at St Paul's Cross provided a copy of the sermon before they preached: MacLure, The Paul's Cross Sermons, I534-I642, p. I3. No letters appointing preachers for the Elizabethan or Jacobean period have been located, but three from the early Tudor period have been found. Two are to Matthew Parker, the first from Thomas Cromwell ([I537]), the second from Nicholas Ridley ([1550?]) (Parker Library, Corpus Christi College, Cambridge, MS I I 4, items I 29 and I33). The letter from Cromwell is reprinted in Correspondence of Matthew Parker, ed. John Bruce and T. Perowne (Parker Society, I853), p. 5. The third letter is from Dr Haynes and the addressee is unknown. Internal evidence suggests a date of I 534 (Parker Library, Corpus Christi College, Cambridge, MS ro6, item 68). In none of these letters is the preacher asked, or commanded, to have a copy of his sermon ready beforehand.

${ }^{23}$ On preachers delivering the 'wrong' message to Queen Elizabeth, particularly Alexander Nowell's disastrous sermon on Ash Wednesday I 565, see McCullough, Sermons at court, pp. 46-8, $67,93)$. For preachers who delivered political, dangerous or unwelcome messages from Paul's Cross, see MacLure, Register of sermons preached at St Paul's Cross, rev. edn. pp. 86, I oo, I I I, I I6-i 7 , I 2 I, I 23 .

${ }^{24}$ Ferrell, Government by polemic, p. I9. A similar awareness of the need to utilize the rhetorical precision of sermons is evident in Ferrell's, 'Donne and his master's voice, I6 $15^{-1} 625$ ', Fohn Donne fournal, i I ( 1992), pp. 59-70.

${ }^{25}$ Perry Miller's The New England mind: the seventeenth century (Harvard, I954); Sacvan Bercovitch, The American Feremiad (Madison, I978); David Minter, 'The puritan Jeremiad as a literary form', in Sacvan Bercovitch, ed., The American puritan imagination: essays in revaluation, (Cambridge, 1974), pp. 45-55. On the Jeremiad, see also Theodore Dwight Bozeman, To live 
preaching as a social phenomenon more generally. Both writers succeed in marrying their descriptions of New England's evolving identity with their discussions of the rhetorical forms within which, and through which, that identity was created. They show the ideological and intellectual/theological assumptions that dictated the particularly stylistic characteristics of the New England sermon as it developed over the first century and a half of the colony. ${ }^{26}$ Toulouse's sensitive reading of these texts and her careful description of the interdependence of style and homiletics should serve as an example to writers on the English sermon. In particular, the analogy she creates between the seamless structure of Emerson's sermons with his belief in the self-evident nature of truth and the importance of individual action is compelling. Like most sermon scholars, however, Toulouse reaches the conclusion that 'the knowledge which New England sermons as cultural constructions can offer about social assumptions and social structure demands more investigation ${ }^{2}{ }^{27}$

In Britain and Ireland until recently, however, the study of a sermons as text rather than 'primary source' has been the concern of literary scholars. Yet the early preoccupation of those studying sermons as texts made their studies rather inwardlooking and have set in place interpretative structures that have, until recently, proved almost as much a hindrance as a help. Research into sermons lost sight of the interventionist nature of preaching rhetoric and became entrenched in the history of English prose style. The investigations of these literary historians, most famously George Williamson, emphasized the 'development' of particular stylistic features of modern English prose through their discussions of sermons. ${ }^{28}$ The greatest mixed blessing these studies have left us is the bifurcation of seventeenth-century sermon styles into 'metaphysical' and plain, a distinction that owes more to the now-defunct classification of Donne and Herbert as 'metaphysical' poets than any contemporary accounts of preaching styles. The scheme is not one derived from the study of preaching rhetoric itself and should, like the term 'metaphysical poetry', be abandoned as a description of a style or a school. ${ }^{29}$ The initial justification for these categories is apparent from W. Fraser Mitchell's English pulpit oratory from Andrewes to Tillotson, the work most responsible for this classification: Mitchell argues that between the time of Donne and Tillotson, English prose as used in the pulpit became 'plain' and 'clear' according to the best advice of Royal Society pundits like Spratt and Wilkins. The reason for this change in style was sought from within the corpus of sermons and the biographies of their authors. The solution arrived at by Mitchell is that the styles used in the pulpit during the transitional phase (between Donne and Tillotson) was determined by the ideological leanings of the individual preachers: puritans practised a plain style that

ancient lives: the primitivist dimension in puritanism (Chapel Hill, I 988), pp. 3 I 2-43; Stephen Foster, The long argument: puritanism and the shaping of New England culture, I570-I700 (Chapel Hill, I99I), pp. 31 $2-20$.

${ }^{26}$ Harry Stout, The New England soul: preaching and religious culture in colonial New England (Oxford, I 986); Teresa Toulouse, The art of prophesying: New England sermons and the shaping of belief (Georgia, I987). See also Marie Ahearn, The rhetoric of war: training day, the militia and the military sermon (New York, I 989). $\quad{ }^{27}$ Toulouse, The art of Prophesying, p. I8I.

${ }^{28}$ George Williamson, The Senecan amble: a study in prose form from Bacon to Collier (London, I 95 I), pp. $23 \mathrm{I}-74$.

${ }_{29}$ The introductions of both Fraser Mitchell's and Horton Davies's studies of 'metaphysical' preaching explicitly state that the classification is borrowed from poetry, and in particular from the classification of Donne the 'preacher-poet' as a 'metaphysical'.

\section{CAMBridge JDURNALS}


mirrored their desire to strip all superfluous ornaments from the word as from the sacraments. Yet their 'crumbling' of the scriptural text, on which they depended for form and structure, lent a digressive and prolix quality to their sermons. 'Metaphysical' preachers used an ornate, 'witty', and complex style that reflected their Anglican, or indeed 'Anglo-Catholic', affiliations. The subsequent triumph of the 'plain style' was not only a product of the general intellectual shift of the Restoration and eighteenth century away from 'metaphysical' quiddities; it was also a reaction against the excesses of the doctrinal complications, and therefore controversies, stirred up by both puritan plain and 'Anglican' metaphysical styles:

Men of the Restoration period had become tired of all the various 'methods' of preaching, and were seeking to adapt their theory of preaching in a way more suited to the needs and tastes of their time ... the good sense of Charles II in this particular, the ideals of the Royal Society, the influence of the French preachers into close contact with whom many influential Englishmen of the period had been thrown, and the general desire of the nation which wished to escape from the extremes and extravagances of all kinds combined in shaping a theory, which, if much less definitely articulated than some of the older artes concionandi yet was representative of the literary beliefs of the day.

The history of prose styles can be as whiggish as any other, and Mitchell's description of English preaching rhetoric reached its telos in the golden age of Tillotson; from then on, eighteenth-century English preaching sustained a 'norm of dignified, sustained, and beautifully modulated prose', even to the fault of excessive polish, until the Methodists upset this balance. ${ }^{30}$ Although there are contemporary comments that seem to encourage this interpretation of two well-understood 'styles' fitting political affiliations, on balance the evidence is slight and has been overstated. Perry Miller's claim that styles were 'not a matter of taste and preference' but 'a party badge' is difficult to support when even John Donne, the archetypal 'metaphysical preacher' said that he wished to 'preach plainely to every capacity'. ${ }^{31}$

This rather acid analysis of Mitchell's book is, I think, necessary and indeed long overdue. Yet in spite of the continuing influence of his schematic account much good work on seventeenth-century preaching styles has been done: James Downey and Rolf P. Lessenich have taken Mitchell's teleology to task by reaffirming the literary and cultural importance of the eighteenth-century pulpit, Downey by showing the reaction of seven famous preachers to the 'Age of Reason', Lessenich by describing the stillvigorous eighteenth-century study of the ars concionandi. ${ }^{32}$ Nor should we discount the history of prose style because of the rigidity of previous schemes. Debora Shuger and Peter Auksi have traced the evolution of the ideas of plainness and vehemence that shaped early modern preaching rhetoric from the arguments of the Church Fathers to the Reformation debates. ${ }^{33}$ Their work has given critics a more nuanced understanding of

${ }^{30}$ Mitchell, English pulpit oratory, pp. I 20-I, I 25.

${ }^{31}$ Miller, The New England mind, p. 333; John Donne, A sermon preached at St. Pauls, June 2I, ${ }_{1626}$, in The sermons of Fohn Donne, G. R. Potter and E. M. Simpson, eds., (Io vols., Berkeley CA, I953-62), vII, p. I 98.

${ }^{32}$ James Downey, The eighteenth century pulpit: a study of the sermons of Butler, Berkeley, Secker, Sterne, Whitefield and Wesley (Oxford, I969); Rolf P. Lessenich, Elements of pulpit oratory in eighteenth-century England, I660-I80o (Cologne, I972). Yet an even more recent study of preaching and the 'reform of style' is still very dependent on Mitchell's schematic account of style: Barbara Butler Hickey, 'Style and structure in the sermons of Jeremy Taylor (Ph.D. thesis, Notre Dame, I982).

${ }^{33}$ Debora K. Shuger, Sacred rhetoric: the Christian grand style in the Renaissance (Princeton, I988); Peter Auksi, Christian plain style: the evolution of a spiritual ideal (Montreal, 1995).

\section{CAMBridge JDURNALS}


the ideological assumptions that affected stylistic decisions. Nor should we abandon all attempts to categorize the stylistic features of early modern preaching: here the lead has been taken by Horton Davies, who adopted Mitchell's old schema in order to identify the characteristics of 'metaphysical preaching' in his Like angels from a cloud. ${ }^{34}$ Davies resists the temptation of using his stylistic division as a political one, carefully describing the divergent ecclesiological and political leanings of his metaphysical preachers.

Unfortunately, the care Davies took has not characterized all investigations of preaching style and the opposition between styles and church 'parties' described by Mitchell has given rise to considerable methodological laziness. There is a reflex apparent in early modern studies by which 'puritanism' can be proven by no more forceful an argument that the absence of excessive rhetorical ornament in preaching. This easy association of styles and preaching philosophies has also papered over the need for a much more thorough and careful study of early modern preaching rhetoric. As the studies of Lake, Fincham, and others have shown the 'Anglican vs. puritan' (or 'puritan vs. Anglican') dichotomy to be a wholly inadequate framework for the study of early modern religious culture, surely it cannot be sufficient for studying the textual sources of that culture? Likewise, if our knowledge of Elizabethan and Jacobean poetics conventions allows us to see the conventionality of the 'metaphysical poets' ${ }^{35}$ surely it is time we examined what is conventional in 'metaphysical preaching', indeed how many characteristics they share with their 'plain style' fellows. The survival of the 'metaphysical' tag is, in large part, a product of the lack of communication between the literary and historical scholars engaged in sermon studies. Sermons are rhetorical works - text written to influence events - and so they must be studied in an interdisciplinary way, with equal emphasis on the text and the event, or we risk being at least half-wrong in our conclusions.

None the less, there are signs of a growing interest in a more accurate, less teleological reading of sermons by literary scholars. This move is partly a response by historicist critics to the agenda set by the revisionist historians. There is also, however, an independent move towards the study of politically engaged literature more generally, which is evident from the emphasis now given to Renaissance rhetoric in literary studies. The study of individual preachers, notably John Donne and Lancelot Andrewes, is reflecting a greater understanding of the importance of context and rhetorical decorum - adapting to the demands of the time, place, and persons before whom one speaks - in the study of sermons. Although Lancelot Andrewes has excited less interest to date, a recent full length monograph by Nicholas Lossky goes some way to redress this. ${ }^{36}$

In Donne studies in particular, we are beginning to see far more work, mostly of article length, on particular sermons on particular occasions. The influence of the political climate on Donne's deployment of rhetoric has been most effectively dealt with in the recent work by Jeanne Shami. Her recent edition of the manuscript copy of Donne's i 622 Gunpowder Plot sermon demonstrates conclusively that sermons speak to 'their time and place', and supports her argument that Donne carefully modulated his criticism of royal policy according to the dictates of his role as a preacher and decorum in

\footnotetext{
${ }^{34}$ Horton Davies, Like angels from a cloud: the English metaphysical preachers, I558-1645 (San Marino, I986).

${ }^{35}$ See Rosemond Tuve, Elizabethan and metaphysical imagery: Renaissance poetry and twentieth-century critics (Chicago, i 947).

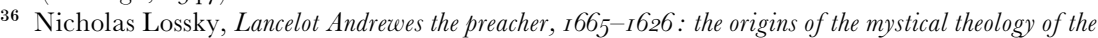
Church of England, trans. Andrew Louth (Oxford, I99I).
}

\section{CAMBRIDGE JDURNALS}


addressing the king. ${ }^{37}$ Without contextualizing Donne's preaching, the restrictive focus on an individual preacher, particularly one so idiosyncratic, makes it difficult to analyse his writings accurately: it becomes impossible to determine what is a characteristic unique to the writer and what is a convention of preaching rhetoric being used or adapted by him. Concentrating on particular preachers has helped us lay out some of the broad categories and terminology suitable for the discussion of sermon prose but it makes it difficult to measure the impact of rhetorical decorum on the performance or publication of a particular sermon. For example, Donne's preaching has been read by two of his biographers (R. C. Bald and John Carey) as demonstrative of his absolutist politics, and other writers, notably Debora Shuger, have levelled similar charges of political and 'theological absolutism' against Donne on the basis of inaccurate and uncontextualized readings of his political sermons. ${ }^{38}$ Jeanne Shami's comparison of Donne's i 622 sermon with the Directions concerning preachers the focus of much of these critics' attention, has shown the importance of rhetorical convention to the understanding of Jacobean preaching. She compares Donne's sermon to other political sermons by Jacobean court preachers, especially Joseph Hall, and finds that Donne's rhetorical strategy is not extremist or absolutist, but rather focuses on the middle course, making 'flexible discriminations sensitive to the times'. ${ }^{39}$ In short, it is only Donne's extraordinary linguistic and rhetorical skill that makes this sermon unusual.

There are, therefore, difficulties in interpreting and assessing the impact of early modern preaching, because we no longer understand the generic and stylistic assumptions according to which these sermons were written. We do not understand the method used in constructing arguments or the presuppositions about what constituted a 'good' or 'bad' sermon. It is clear that there were well-understood conventions for the interpretation of Scripture within the constraints of which all preachers operated if they wished to avoid the accusation of 'wrested' Scripture to their own ends. There is clear anecdotal evidence for this from John Chamberlain's letters. In July i624, the lord keeper, Bishop Williams, preached to the city council as it debated subsidies for war with Spain. He argued that disguising wealth to avoid paying taxes was to commit the sin against the Holy Ghost, the notorious sin that could not be forgiven. Rather snidely Chamberlain comments that this thesis was 'scant receved as Catholike [that is, universal] doctrine'. Williams was guilty of 'wrestling' Scripture, of misusing it as the basis of a sophistic argument that ran contrary to church teaching.

${ }^{37}$ Jeanne Shami, Fohn Donne's I622 Gunpowder Plot sermon: a parallel-text edition (Pennsylvania, I 996); idem, 'Donne on discretion', ELH, 47 ( I980), pp. 48-66; idem, 'Kings and desperate men: John Donne preaches at court', Fohn Donne Fournal, 6 (1987), pp. 9-23; idem, 'Introduction: reading Donne's sermons', fohn Donne fournal, i I ( I992), pp. I-20; idem, 'Donne's sermons and the absolutist politics of quotation', in Raymond-Jean Frontain and Frances M. Malpezzi, eds., Donne's religious imagination: essays in honor of John Shawcross (Conway, AR, I995), pp. 380-4I 2.

${ }^{38}$ R. C. Bald writes that Donne was 'at least in part, in sympathy with the King's directions', which he interprets as effectively stifling opposition to the king's policies, but that Donne's sermon 'scarcely touches the real issues' by presenting the Directions as 'unexceptionable': Fohn Donne a life, pp. 433-5. A more extreme statement is made by John Carey, who writes that 'Donne, the absolutist, was stirred by the image of numinous majesty, scattering opposition as the sun disperses clouds': Fohn Donne: life, mind and art (London, i98 I repr. 1990), p. го2; Debora Shuger's, 'Absolutist theology: the sermons of John Donne', in Habits of thought in the English Renaissance: religion, politics, and the dominant culture (Berkeley, CA, I990), pp. I59-2 I8.

${ }^{39}$ Jeanne Shami, "“The stars in their order fought against Sisera": John Donne and the pulpit crisis of I622', Fohn Donne Fournal, I4 (1995), pp. I-58.

\section{CAMBridge JDURNALS}


Literary studies have not truly accounted for 'the particularity of past events' in the way that historians have sought to do, because we have tended to concentrate on comparing styles between individuals and periods, rather than examining concentrating on the particular sermon and its immediate historical moment. Again, we must think of sermons as both text and event, and work with the particularity of terms of style and context. McCullough's detailed description of court preaching goes a long way towards achieving this. He corrects the appalling neglect by historians of the context of court preaching: not just the schedule and ceremonial of these events, but the physical surroundings of the king, court, and preacher in the palaces of England and Scotland. Consequently, we can see the immediate situation in and through which the preacher addresses his exhortation to the king. Among the most fascinating aspects of McCullough's research is the contrast he discovered in the physical position of the preacher vis-à-vis the king in England and Scotland. Whereas the English king sat in a closet above his courtiers and preacher, the Scottish king sat below the pulpit in Holyrood House. McCullough comments: 'Just as the English arrangement of elevated closet-over-chapel articulated the royal supremacy by placing the monarch literally above the nobles and clergy, the Scottish custom summed up the kirk's insistence that it was not subject to earthly princes. ${ }^{40}$

My only criticism of McCullough's book is that there is too little analysis of individual texts, although there is some. As McCullough is a literary scholar (having begun his research into court preaching in order to work on Lancelot Andrewes), this unbalance is a testimony to the neglect of the subject until now: before the impact of a particular preaching event and its transmission to be print can be analysed almost every aspect of the context of the event - the physical, ceremonial, and liturgical circumstances in which it took place - needed to be described.

In conclusion, therefore, McCullough's and Ferrell's monographs demonstrate the enormous potential for early modern studies in the investigation of sermons as 'political actions' and rhetorical texts. Their authors rightly insist that there is considerable research still needed before we can claim to have a methodology that uncovers a sermon's full engagement with its historical moment. Such a method would go a long way towards allowing us to recover the 'particularity of past experience'.

40 McCullough, Sermons at court, p. 28.

\section{CAMBridge JDURNALS}

